Marquette University

e-Publications@Marquette

Exercise Science Faculty Research and Publications

Exercise Science, Department of

$5-1-2011$

Is There a Sex Difference in the Age of Elite Marathon Runners?

Sandra K. Hunter

Marquette University, sandra.hunter@marquette.edu

Alyssa A. Stevens

Marquette University

Kelly Magennis

Marquette University

Katalin W. Skelton

Marquette University

McKenzie Fauth

Marquette University

Accepted version. Medicine \& Science in Sports \& Exercise, Volu. 43, No. 4 (May 2011). DOI:

10.1249/MSS.0b013e3181fb4e00.

This is a non-final version of an article published in final form in Medicine \& Science in Sports \& Exercise. 


\title{
Is There a Sex Difference in the Age of Elite Marathon Runners?
}

\author{
Sandra K. Hunter \\ Exercise Science Program, Department of Physical Therapy \\ Marquette University \\ Milwaukee, WI \\ Alyssa A. Stevens \\ Exercise Science Program, Department of Physical Therapy \\ Marquette University \\ Milwaukee, WI \\ Kelly Magennis \\ Exercise Science Program, Department of Physical Therapy \\ Marquette University \\ Milwaukee, WI \\ Katalin W. Skelton \\ Exercise Science Program, Department of Physical Therapy \\ Marquette University \\ Milwaukee, WI \\ Mckenzie Fauth \\ Exercise Science Program, Department of Physical Therapy \\ Marquette University \\ Milwaukee, WI
}


NOT THE PUBLISHED VERSION; this is the author's final, peer-reviewed manuscript. The published version may be accessed by following the link in the citation at the bottom of the page.

\begin{abstract}
Purpose: The purposes of this study were to determine i) if there is a sex difference in the age of the elite marathon runners and ii) if the sex difference in performance altered across the years that women have participated in the marathon.

Methods: Age at time of competition and running times of the first five placed male and female runners who competed in the seven marathons of the World Marathon Majors Series were analyzed. Data from as many years as was available online were retrieved so that 410 men and 410 women were included in the analysis. The marathons and years included the Berlin (19992009), Boston (2000-2009), Chicago (1997-2009), London (2001-2009), New York City (1990-2009), International Athletic Association Federation World Championship (1983, 1987, and every 2 yr from 1991), and Olympic (every 4 yr since 1984) marathons.

Results: Women were older than men (mean \pm SD $=29.8 \pm 4.2$ vs $28.9 \pm$ $3.8 \mathrm{yr}$ ), but for only two of the seven marathons, the Chicago and the London marathons $(P<0.05)$ : the sex difference in age was not consistent across the years. There was no sex difference in age for the Berlin, Boston, New York City, World Championship, and Olympic marathons. Men were faster than women $(11.6 \% \pm 1.8 \%)$. The sex difference in running velocity varied across marathons (least for the World Championships, 10.2\%) and also across years, but not systematically. This sex difference in running velocity increased from first to fifth place across all marathons.

Conclusions: These data indicate that men and women physiologically peak at a similar age in marathon running performance. The sex difference in performance of elite marathon runners varied across years but has not systemically decreased or varied since the 1980 s.
\end{abstract}

There are physiological sex differences that explain the faster performance of men compared with women for distance running events $(3,12)$. On average, men have larger hearts, less body fat, greater hemoglobin concentration and muscle mass per unit of body weight, and larger maximal oxygen consumption $(3,12,20)$ that contributes to the faster running times compared with women. The speculation that women would eventually outperform men on the basis of rates of improvement in running times (23) is largely put to rest because the magnitude of the sex difference of the world's best times has been maintained in more recent years for the marathon and other distance races $(1,3,9,12,21)$. Sociological factors likely played a large role in the rapid improvement in women's running performance $(3,9,12)$. Although the magnitude of the sex difference in performance among elite runners is known (3), recent marathon race results suggest that the elite women marathon runners may be older than the men, therefore suggesting that there is a sex difference in the age of peak performance in marathon running. In the 2008 Beijing Olympic

Medicine \& Science in Sports \& Exercise, Vol. 43, No. 4 (May 2011): pg. 656-664. DOI. This article is (C) American College of Sports Medicine and permission has been granted for this version to appear in e-Publications@Marquette. American College of Sports Medicine does not grant permission for this article to be further copied/distributed or hosted elsewhere without the express permission from American College of Sports Medicine. 
marathon, for example, there was a 17-yr age difference between the men's and the women's gold medalist (21 vs $38 \mathrm{yr}$ ). Understanding whether men and women differ in the age at which they reach peak performance for marathon running would raise the possibility of physiological or sociological sex differences that vary with age and are not yet understood.

Physiological reasons for any sex difference in the age of elite marathon runners are plausible if the factors that limit marathon performance are influenced by age more in one sex than the other. Both men and women appear to be limited in distance running performance by their maximal oxygen uptake $\mathrm{V} \cdot \mathrm{O}_{2 \max }$, running economy, and exercise intensity at which a high percentage of the maximal oxygen consumption can be maintained (also known as the "lactate threshold") $(3,11-13,18,22)$. The larger capacity of men to consume oxygen $\left(\mathrm{V} \cdot \mathrm{O}_{2 \max }\right)$ per body weight appears to be the primary factor determining the sex difference in distance running $(2,5,12)$. These factors, however, also change with advanced age $(6,8,22)$. Older adults, for example, have lower ( $\mathrm{V} \cdot \mathrm{O}_{2 \max }$ ) (a primary factor being a lower maximum heart rate $(7,19)$ ) and lower "lactate threshold" that lead to a slower running velocity compared with young adults (22). Thus, if men and women age at different rates in those factors that limit distance running performance, even at relatively young ages, then women may peak physiologically at a later age than men. Alternatively, there could be unidentified sociological factors that drive a sex difference in age of peak performance that are yet to be understood. Given that women have only competed internationally in the marathon distance since the early 1980s, sociological factors may still play a role in the age of women runners compared with men. The purpose of this study, therefore, was to compare the age of the first five men and women runners in each of the seven marathon races in the World Marathon Majors Series. A secondary purpose was to determine whether the age of the first five men and women varied across years to expose any period-based sex difference in age. A third purpose was to compare the velocity of the men and women across years within each marathon to determine whether the sex difference in performance altered across the years.

Medicine \& Science in Sports \& Exercise, Vol. 43, No. 4 (May 2011): pg. 656-664. DOI. This article is (C) American College of Sports Medicine and permission has been granted for this version to appear in e-Publications@Marquette. American College of Sports Medicine does not grant permission for this article to be further copied/distributed or hosted elsewhere without the express permission from American College of Sports Medicine. 
NOT THE PUBLISHED VERSION; this is the author's final, peer-reviewed manuscript. The published version may be accessed by following the link in the citation at the bottom of the page.

\section{Methods}

Data from 410 men and 410 women were analyzed from seven different marathons that constitute the World Marathon Majors Series. The World Marathon Majors Series includes the five annual marathons: the Boston, London, Berlin, Chicago, and New York City marathons as well as the International Athletic Association Federation World Championship (1983, 1987, and every 2 yr from 1991) and the Olympic marathons (every 4 yr since 1984). For each marathon, the age at the time of competition and the finishing time of the first five men and women runners were recorded across as many years as the data were publically available online (Table 1 ). Data were retrieved from the following online Web site sources: http://www.iaaf.org (International Association of Athletics Federations), http://www.usatf.org (USA Track and Field), http://www. marathonguide.com (Marathon Guide), http://www.worldmarathonmajors.com/US (World Marathon Majors), http://www.nycmarathon.org (ING New York City Marathon), http://www. chicagomarathon.com (Bank of America Chicago Marathon), http://www.realberlin - marathon.com (SCC Running realBerlin Marathon), http://www.virginlondonmarathon.com (Virgin London Marathon), and http://www.bostonmarathon.org (Boston Athletic Association). Data were found for the Olympic and World Championship marathons for all the years that women have been permitted to compete in the marathon. Table 1 shows the range and the total number of years that data were able to be retrieved online as well as the numbers of men and women that contributed to each marathon data set.

\section{Data Analysis}

Data (ages and running velocities) were analyzed for the winners (first place) and were also averaged across the first five men and women. Running velocities were calculated from the finishing times. To determine the influence of a runner winning or placing in multiple marathons within a year at the same age, analysis of the age was performed under two conditions: (i) when the ages of all runners were included in the analysis (410 men and 410 women) and (ii) with the runners who had placed in the top five in multiple marathons at 
the same age included only once within that year. The inclusion and exclusion criteria for the second analysis were as follows: If a runner placed in the top five for multiple marathons at the same age, only one marathon would be included in the analysis, and the other data points were excluded for the remainder of the marathons during which the runner was at that same age. If a runner placed first and also placed in several other marathons that year at the same age, the marathon in which the runner placed first would be included regardless of when the marathon occurred during the year. If the same runner placed first in multiple marathons, the marathon they won most recently after their birthday was included, and their age data were excluded from the remaining marathons during which they were of that age. If there were multiple marathons in which the same runner placed second to fifth but with no first-place finishes, the same exclusion criteria as for multiple first-place finishes were applied. Hence, the marathon that a runner placed in most closely after their birthday would be kept, and the rest of the data points would be excluded. When all exclusion criteria were applied for this second analysis, there were 371 men and 354 women.

\section{Statistical Analysis}

Data were reported as mean \pm SD within the text and displayed as mean \pm SEM in the figures. Statistical analysis was performed using the Statistical Package for the Social Sciences for Windows (Version 18.0, SPSS Inc., Chicago, IL). Univariate ANOVA was used to determine whether there was a sex difference in the age of the marathon runners with between-subject factors of sex (men vs women), place (first, second, third, fourth, fifth place), and marathon (Berlin, Boston, Chicago, London, New York City, Olympics, and World Championships). The years were collapsed across each marathon for this analysis because the number of years analyzed varied among the seven marathons. This analysis was repeated for first-place runners only, and therefore place was not included as a factor. For analyses including five places, the analysis was performed twice: once with all runners included and a second time when inclusion and exclusion criteria were applied for runners who placed in multiple marathons at the same age (described in the data analysis section previously). To determine whether the age of men and women (first five runners) of 
each marathon differed across the years, a separate ANOVA with repeated measures on year and with sex as a between-subject factor was performed for each marathon. Post hoc analysis (Tukey-Kramer) was used to test for differences among pairs when appropriate.

Univariate ANOVA was used to determine the sex difference (difference between men and women as a percentage of the men) in the mean running velocity of the marathon finishers across marathon (Berlin, Boston, Chicago, London, New York City, Olympics, and World Championships) and place (first, second, third, fourth, and fifth place). The years in each marathon were collapsed for this analysis because the number of years that data were available to be analyzed varied among the marathons. For each marathon, a separate ANOVA with repeated measures on time (year) and place as a between-subject factor was performed to determine whether the sex difference in velocity of runners differed across the years for each marathon. Post hoc analysis (Tukey-Kramer) was used to test for differences among pairs when appropriate. For all analyses, a significance level of $P<$ 0.05 was used to identify statistical significance.

\section{Results}

\section{Sex Differences in Age of Marathon Runners}

Women were older than men $(29.8 \pm 4.2 \mathrm{vs} 28.9 \pm 3.8 \mathrm{yr}$, respectively; sex effect, $P=0.003$ ) when all the first five men and women (places 1-5) were included for all seven marathons and all the years were analyzed (Fig. 1A). The main effect of sex, however, was specific to two of the seven marathons. Women were older than men for the Chicago and London marathons but not for the Berlin, Boston, New York City, Olympics, and World Championships (sex $\times$ marathon interaction, $P=0.024$ ) (Table 1 ). When the analysis was performed applying the exclusion criteria for those men and women who had placed in several marathons within one birth year, the sex difference remained significant because women $(n=354,29.7 \pm 4.3 \mathrm{yr})$ were older than men ( $n=371,28.95 \pm 3.8 \mathrm{yr}$; sex effect, $P=0.017)$. Similar to when all data were included, the sex difference was specific to the Chicago and London marathons but not to the Berlin, Boston, 
NOT THE PUBLISHED VERSION; this is the author's final, peer-reviewed manuscript. The published version may be accessed by following the link in the citation at the bottom of the page.

New York City, Olympic, and World Championship marathons (sex $\times$ marathon interaction, $P=0.005$ ).

\section{First Place}

The winners of each marathon were also analyzed separately. The women who placed first $(n=82)$ were older than the men who placed first ( $n=82, P=0.042$; Fig. 1B). This sex difference, however, was specific to two marathons, the Chicago and the London marathons, and not the other five marathons (sex $\times$ marathon interaction, $P=0.044$ ) (Table 1 ).

\section{Place of Runner}

There was no difference in the age of the men and women across the first five placed runners (place effect, $P=0.23$ for all and $P$ $=0.40$ when the runners who placed multiple times in a birth year were included once). When all the men and the women were included, there was an interaction for sex and place $(P=0.025)$, but this interaction disappeared when those who had placed multiple times within $1 \mathrm{yr}$ were included once $(P=0.14)$. There were no other interactions (marathon $\times$ sex $\times$ place, $P=0.63$ ).

\section{Sex Difference in Age Across Years}

Each marathon an interaction for sex and place $(P=0.025)$, but this interaction disappeared when those who had placed multiple times-was analyzed separately to determine whether the age of men and women differed across the years for the first five runners (Fig. 2). Consistent with the group analyses, there was a sex difference in age for both the London and the Chicago marathons because the women were older than the men (Figs. $2 \mathrm{C}$ and D). For the Chicago marathon, there was an interaction of quadratic trends in age for men and women across the years (quadratic trend interaction of year $\times \operatorname{sex}, P$ $=0.019$ ) because the sex difference in age was greater in the first (1997) and the last (2009) years analyzed (Fig. 2C). For the London marathon, there was an interaction of sex and time $(P=0.03)$ because the age difference between men and women was specific to the more recent years (2008 and 2009). 
Both the World Championship and the New York City marathons showed a difference in age of the runner across the years (year effect, $P<0.05$ ), but the age difference was similar for men and women (no sex differences or interaction of sex $\times$ year, $P>0.05$ ). For the New York City marathon, there was a progressive increase in age of both men and women with a more rapid increase from 2006 onward (Fig. $2 \mathrm{E})$. The mean age of the first five men and women runners in the 2009 New York City marathon for example was greater than the age of the first five runners in the years between 1991 and $2006(P<0.05)$. There was also a difference in age within the World Championship marathon over the years $(P<0.05)$. Both men and women, for example, were younger in 2009 than seven of the other years, including 1983, 1987, 1991, 1995, 1997, 2005, and $2007(P<0.05$;

Fig. 2F). For all other marathons, including the Berlin, Boston, and Olympic marathons, there was no sex difference in age, no difference in age between the years analyzed for each marathon, and no interaction of year and sex (Figs. 2A, B, and G).

\section{Sex Differences in Velocity of Marathon Runners}

Men were faster than women by $11.63 \% \pm 1.84 \%$ when the first five men and women were pooled for all marathons and across all the years analyzed. This sex difference varied across marathons (effect of marathon, $P<0.001$ ), with the greatest sex difference in velocity in the Berlin and Chicago marathons $(P<0.05)$ and the least in the World Championships (Table 2). The sex difference in running velocity for the World Championships was less than the sex difference for the Berlin, Chicago, and New York City marathons $(P<0.05)$ but similar to the sex differences for the Boston, London, and Olympic marathons $(P>0.05)$.

The sex difference in average running velocity also differed with place (effect of place, $P=0.001$ ) because there was an increase in the sex difference from first to fifth place $(10.97 \% \pm 1.99 \%$ to $12.16 \% \pm$ $1.88 \%$, respectively; Fig. $3 \mathrm{~A})$. There was no interaction of marathon and place $(P=0.99)$, indicating that the slightly widening sex difference between first and fifth place occurred within each marathon (Fig. 3B). When first-placed runners were analyzed separately, the sex

Medicine \& Science in Sports \& Exercise, Vol. 43, No. 4 (May 2011): pg. 656-664. DOI. This article is (C) American College of Sports Medicine and permission has been granted for this version to appear in e-Publications@Marquette. American College of Sports Medicine does not grant permission for this article to be further copied/distributed or hosted elsewhere without the express permission from American College of Sports Medicine. 
NOT THE PUBLISHED VERSION; this is the author's final, peer-reviewed manuscript. The published version may be accessed by following the link in the citation at the bottom of the page.

difference in velocity was consistent across marathons (marathon effect, $P=0.65$ ).

Sex Difference in Velocity Across Years

Each marathon race was analyzed separately to determine whether the mean running velocity of the first five men and women differed across the years. The sex difference in velocity differed across the years analyzed for all the marathons $(P<0.001$, Fig. 4$)$, except for the Berlin marathon $(P=0.15)$. The relative sex difference between the first five men and women is shown for each marathon across the years in Figure 4.

\section{Discussion}

The novel findings of this study were that there was no sex difference in age for the first-place and the first five placed runners for five of the seven marathon races in the World Marathon Majors Series. These marathons included the Olympic and World Championship marathons, for which data were examined for all the years that women have officially competed in the marathon event, as well as the Berlin, Boston, and New York City marathons. Women sex difference in age for the first-place and the first five were, however, older than men for the London and Chicago marathons on average by $2.3 \mathrm{yr}$, but this difference was not consistent across the years examined. These are the first data to examine the age of marathon runners, indicating that elite women marathon runners are not older than elite men for many of the premiere marathons. Furthermore, there was a sex difference in mean running velocity that differed across the various marathons and over the years within each marathon for six of the seven marathons but not systematically across the years. The sex difference in running velocity also increased from first to fifth place across all marathons.

\section{Age of Elite Marathon Runners and Sex Differences}

The sex difference in age was specific to two of the seven marathons. Women were 2.5 and $2.1 \mathrm{yr}$ older than men for the Chicago marathon (1998-2009) and the London marathon (20012009), respectively. For both marathons, the sex difference was not 
significant across all the years examined but common to both marathons in the more recent years. Thus, for many of the years between 2000 and 2008, the age of the men and women was similar (Fig. 2). Consequently, across all the marathons, there was no clear evidence for a difference in the age of the men and women runners that varied systematically across years.

Although women were older than men for the Chicago and London marathons, this study provides indirect evidence that there is no sex difference in the physiological determinants of the age at which men and women peak in marathon performance. First, the sex difference for the Chicago and London marathons was not representative of the other marathons in the World Marathon Majors Series. The age of men and women was similar for the top five and first-place runners in the Berlin, Boston, New York City, Olympic, and World Championship marathons. For the Olympic and World Championship marathons, available data were analyzed across all the years that women have been permitted to compete officially. These two marathons are also considered the premiere and most prestigious marathons to win. Furthermore, the sex difference in velocity of running times was the least for the Olympic and World Championship marathons compared with the other five marathons. The data from the Olympic and World Championship marathons therefore are more likely to represent whether any age difference between men and women exists as a physiological manifestation.

Second, the sex differences in age for the elite runners in the Chicago and London marathons were small ( $\sim 2.3$ yr on average) and occurred within an age range in which such an increase in age would have minimal deleterious effects on running performance. Marathon running performance begins to decline from $40 \mathrm{yr}$ on for elite men and women runners with minimal age-related changes in running performance for both men and women before this age $(10,16,22)$. Accordingly, both men and women appear to be physiologically limited by their maximal oxygen uptake $\left(\mathrm{V} \cdot \mathrm{O}_{2 \mathrm{max}}\right)$, "lactate threshold," and running economy $(3,11,12,22)$. Most of the decrements in running performance with age are due to changes in maximal oxygen uptake $\left(\mathrm{V} \cdot \mathrm{O}_{2 \mathrm{max}}\right)$, with some contribution from alterations in "lactate threshold" resulting in a slowing of mean running velocity of both men

Medicine \& Science in Sports \& Exercise, Vol. 43, No. 4 (May 2011): pg. 656-664. DOI. This article is (C) American College of Sports Medicine and permission has been granted for this version to appear in e-Publications@Marquette. American College of Sports Medicine does not grant permission for this article to be further copied/distributed or hosted elsewhere without the express permission from American College of Sports Medicine. 
and women (22). Our study provides further evidence that the physiological determinants of the age that men and women reach peak marathon performance must be similar for both sexes. Thus, taken together, these results indicate that the sex differences in age were specific to two marathons within particular years and therefore not representative of physiological sex differences that determine the age at which men and women peak in marathon performance.

The sex difference in age for the Chicago and London marathons was consistent whether we controlled for the same runners winning or placing multiple times in one birth year. This analysis, however, did not control for runners who continually placed in the top five for several consecutive years. It is unclear what factors contributed to the sex difference in age for the Chicago and London marathons and not the other marathons. One plausible factor that may influence the age of the men and women is topographic profiles of the marathons. The London and Chicago marathons have the least elevation gain and loss over the marathon course compared with the other three marathons that are competed in the same city each year (Berlin, Boston, and New York City) (17). Older women may be more competitive against a younger runner when running on the relatively flatter courses such as the Chicago and London marathons compared with other marathons that have greater elevation gain and loss. The advantage, however, would need to be less for men if this were the case. Although the reason that women are older than men for Chicago and London marathons is not fully understood, the factors contributing to these sex differences are not likely driven by factors directly related to physiological sex differences.

\section{Sex Differences in Running Velocity}

Men were faster than women for all the marathons for first place (10.9\%) and across the first five runners (11.6\%). The sex difference, however, was specific to each marathon: the smallest sex difference occurred in the World Championship marathon (10.2\%: first five runners) and the greatest in the Chicago marathon (12.6\%). The sex differences in running velocities in this current study are consistent with sex differences for distance running reported by others $(3,4,21)$ and appears to reflect physiological differences between men and 
women. On average, men have larger hearts, less body fat, greater hemoglobin concentration and muscle mass per unit of body weight, and larger maximal oxygen consumption $(3,12,20)$. Both men and women appear to be limited in distance running performance by their maximal oxygen uptake ( $\mathrm{V} \cdot \mathrm{O}_{2 \text { max }}$ ), "lactate threshold," and running economy $(3,12,18)$. However, it is the larger capacity of men to consume oxygen $\left(\mathrm{V} \cdot \mathrm{O}_{2 \max }\right)$ per body weight that is the primary factor determining the sex difference in distance running $(3,5,12,14)$.

A major finding of this study was that although the sex difference in performance differed across all analyzed years for most marathons (except the Berlin), the sex difference showed no systematic trend across the years or the different marathons. This was particularly evident for the Olympic and World Championship marathons where data were analyzed for all the years that women have been permitted to officially compete in the marathon. The sex difference in performance times of elite runners has not changed systematically or decreased for the marathon since the mid1980s (21), and our data confirm this observation. It had been argued that women were improving in performance at a greater rate than men, and given this trajectory, they would eventually equal the performance of men $(9,23)$. The more rapid rate of improvement in running performance of women than men over the last 20-30 yr has in part been driven by sociological factors that include the limited opportunities for women to participate in marathon races until the 1970 s and 1980 s $(3,9,23)$. The first Olympic marathon for women was competed in the 1984 Olympics in Los Angeles. The magnitude of the sex difference has stabilized to approximately $10 \%-11 \%$ in more recent years as the opportunity for women to train and to compete has been provided and the physiological limitations of both men and women realized $(3,9,15,16,21)$. Our data support these previous findings for distance running events showing no evidence of an ever decreasing gap in marathon running performance between men and women.

A novel finding of this study was that the sex difference in running velocity increased progressively from the first-placed runners to the fifth-placed runners. This increase was consistent across all the marathons but appeared least for the World Championship marathon (Fig. 3B). The reason for the widening sex difference is not understood

Medicine \& Science in Sports \& Exercise, Vol. 43, No. 4 (May 2011): pg. 656-664. DOI. This article is (c) American College of Sports Medicine and permission has been granted for this version to appear in e-Publications@Marquette. American College of Sports Medicine does not grant permission for this article to be further copied/distributed or hosted elsewhere without the express permission from American College of Sports Medicine. 
but may be related to the lesser number of women runners relative to men who compete in the marathon $(10,17)$. The ratio of women to men participants has continually increased over the years, but there is still a relatively larger pool of male competitors $(10,17)$. In 2009 for example, $59.6 \%$ of the marathon finishers in U.S. marathons (with posted running times) were men and $40.4 \%$ were women (17). Of all these runners who finished the marathon in less than $3 \mathrm{~h}$ (8968 total), $92.5 \%$ were men ( 8293 total men) and $7.5 \%$ were women (675 total women) (17). The greater sex difference in the lower placed runners therefore may be due to a larger clustering of elite men who are closer in running times compared with a more diminished pool of women runners. Further research to understand how the increased participation of women in distance running in more recent years has influenced the sex difference in the average running times at the elite and nonelite level is warranted.

In conclusion, there was no sex difference in the age of the first five runners for five of the seven marathons in the World Marathon Majors Series, including the Olympic and World Championship marathons for which data were collected across all the years that women have competed in the marathon. Rather, women were older than men for two of the seven marathons, the Chicago and the London marathons, and this sex difference was restricted to specific years for each marathon. Thus, there is little evidence to support that women peak physiologically in marathon running performance at an older age than men. Sociological factors not identified likely contribute to the sex difference in age within the Chicago and London marathons. In addition, men were faster than women over the marathon distance in all marathons, and this sex difference was the least for the World Championships for the first five runners. The sex difference increased progressively between first and fifth place, possibly representing differences in the number of men and women runners. Although the sex difference in running velocity has varied across years in many of the marathons, the difference has not systemically decreased or varied since the mid-1980s.

\section{References}

Bam J, Noakes TD, Juritz J, Dennis SC. Could women outrun men in ultramarathon races? Med Sci Sports Exerc. 1997;29(2):244-7. 
NOT THE PUBLISHED VERSION; this is the author's final, peer-reviewed manuscript. The published version may be

accessed by following the link in the citation at the bottom of the page.

Bunc V, Heller J. Energy cost of running in similarly trained men and women. Eur J Appl Physiol Occup Physiol. 1989;59:178-83.

Cheuvront SN, Carter R, Deruisseau KC, Moffatt RJ. Running performance differences between men and women: an update. Sports Med. 2005;35:1017-24.

Coast JR, Blevins JS, Wilson BA. Do gender differences in running performance disappear with distance? Can J Appl Physiol. 2004;29:139-45.

Cureton K, Bishop P, Hutchinson P, Newland H, Vickery S, Zwiren L. Sex difference in maximal oxygen uptake. Effect of equating haemoglobin concentration. Eur J Appl Physiol Occup Physiol. 1986;54:656-60.

Evans SL, Davy KP, Stevenson ET, Seals DR. Physiological determinants of $10-\mathrm{km}$ performance in highly trained female runners of different ages. J Appl Physiol. 1995;78:1931-41.

Fitzgerald MD, Tanaka H, Tran ZV, Seals DR. Age-related declines in maximal aerobic capacity in regularly exercising vs. sedentary women: a metaanalysis. J Appl Physiol. 1997;83:160-5.

Fuchi T, Iwaoka K, Higuchi M, Kobayashi S. Cardiovascular changes associated with decreased aerobic capacity and aging in long-distance runners. Eur J Appl Physiol Occup Physiol. 1989; 58:884-9.

Holden C. An everlasting gender gap? Science. 2004;305:639-40.

Jokl P, Sethi PM, Cooper AJ. Master's performance in the New York City Marathon 1983-1999. Br J Sports Med. 2004;38:408-12.

Joyner MJ. Modeling: optimal marathon performance on the basis of physiological factors. J Appl Physiol. 1991;70:683-7.

Joyner MJ. Physiological limiting factors and distance running: influence of gender and age on record performances. Exerc Sport Sci Rev. 1993;21:103-33.

Joyner MJ, Coyle EF. Endurance exercise performance: the physiology of champions. J Physiol. 2008;586:35-44.

Legaz Arrese A, Munguia Izquierdo D, Serveto Galindo JR. Physiological measures associated with marathon running performance in high-level male and female homogeneous groups. Int J Sports Med. 2006;27:289-95.

Lepers R. Analysis of Hawaii ironman performances in elite triathletes from 1981 to 2007. Med Sci Sports Exerc. 2008;40(10): 1828-34.

Lepers R, Maffiuletti N. Age and gender interactions in ultra-endurance performance: insight from triathlon. Med Sci Sports Exerc. 2011;43(1):134-9.

Marathon Guides Web site. [Internet]. [cited August 28, 2010]. Available from: www. MarathonGuides.com.

Peronnet $F$, Thibault $G$. Mathematical analysis of running performance and world running records. J Appl Physiol. 1989;67: 453-65.

Medicine \& Science in Sports \& Exercise, Vol. 43, No. 4 (May 2011): pg. 656-664. DOI. This article is (C) American College of Sports Medicine and permission has been granted for this version to appear in e-Publications@Marquette. American College of Sports Medicine does not grant permission for this article to be further copied/distributed or hosted elsewhere without the express permission from American College of Sports Medicine. 
NOT THE PUBLISHED VERSION; this is the author's final, peer-reviewed manuscript. The published version may be accessed by following the link in the citation at the bottom of the page.

Pimentel AE, Gentile CL, Tanaka H, Seals DR, Gates PE. Greater rate of decline in maximal aerobic capacity with age in endurance-trained than in sedentary men. J Appl Physiol. 2003;94:2406-13.

Sparling PB. A meta-analysis of studies comparing maximal oxygen uptake in men and women. Res Q Exerc Sport. 1980;51: 542-52.

Sparling PB, O'Donnell EM, Snow TK. The gender difference in distance running performance has plateaued: an analysis of world rankings from 1980 to 1996. Med Sci Sports Exerc. 1998;30(12): 1725-9.

Tanaka $\mathrm{H}$, Seals DR. Endurance exercise performance in Masters athletes: age-associated changes and underlying physiological mechanisms. J Physiol. 2008;586:55-63.

Whipp BJ, Ward SA. Will women soon outrun men? Nature. 1992;355:25. 
NOT THE PUBLISHED VERSION; this is the author's final, peer-reviewed manuscript. The published version may be accessed by following the link in the citation at the bottom of the page.

\section{Appendix \\ Figure 1}
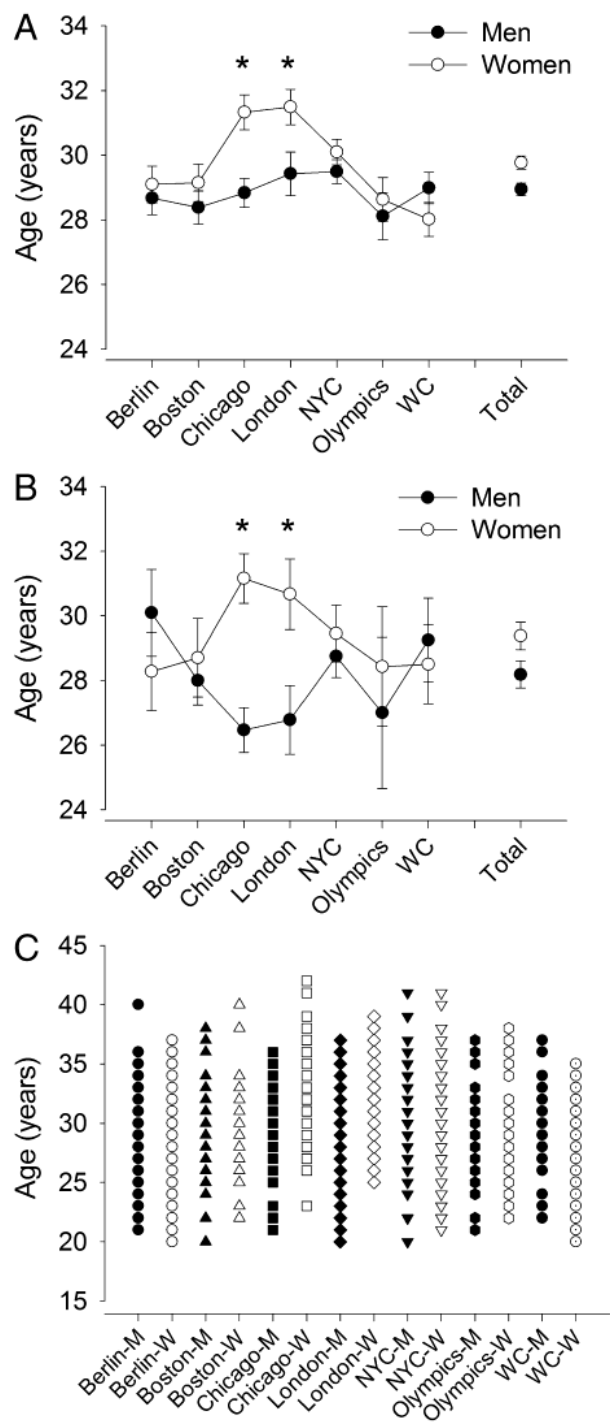

Age (mean \pm SEM) of the top five men and women (A) and first place only (B) for the seven marathons in the World Marathon Majors Series: Berlin, Boston, Chicago, London, New York City (NYC), Olympics, and World Championships (WC). The years analyzed for each marathon are pooled and the mean \pm SEM age of men and women of all the marathoners are shown on the right side of each graph (total). The total is for 410 men and 410 women in panel A and 82 mean and 82 women in panel B. Women were older than men for the Chicago and London marathons when runners for the first five runners $(A)$ and for the first-placed runners $(B)$ (*differences between men and women at $P<0.05$ in panels $A$ and $B$ ). Panel $C$ shows the range and

Medicine \& Science in Sports \& Exercise, Vol. 43, No. 4 (May 2011): pg. 656-664. DOI. This article is (C) American College of Sports Medicine and permission has been granted for this version to appear in e-Publications@Marquette. American College of Sports Medicine does not grant permission for this article to be further copied/distributed or hosted elsewhere without the express permission from American College of Sports Medicine. 
NOT THE PUBLISHED VERSION; this is the author's final, peer-reviewed manuscript. The published version may be accessed by following the link in the citation at the bottom of the page.

individual ages of top five men (M: filled symbols; $n=410$ men) and women (W: open symbols; $n=410$ women) runners in each marathon with all the years analyzed for each marathon included. Each marathon is represented with different symbols.

\section{Figure 2}
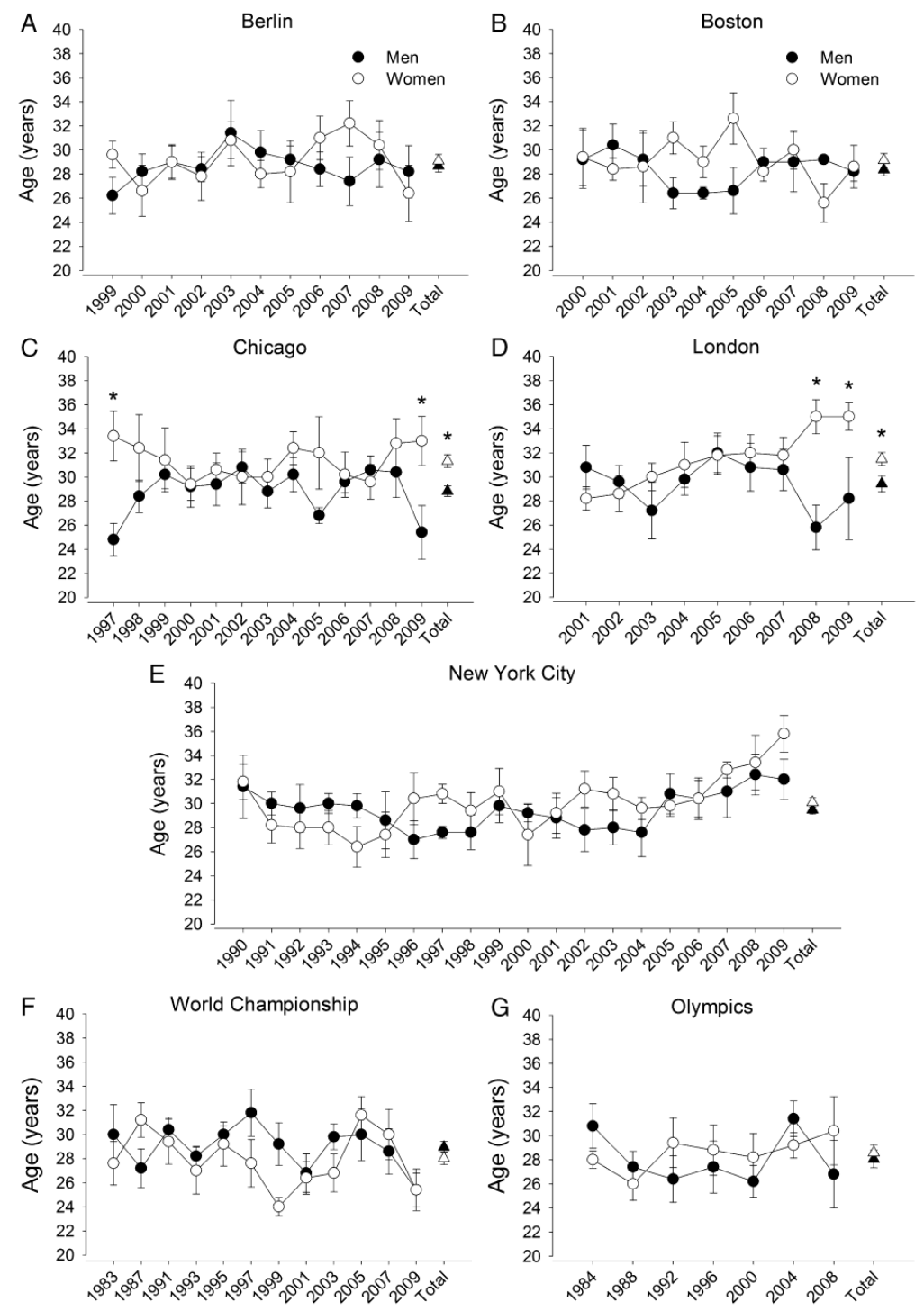

Age (mean \pm SEM) of the top five men $(n=410)$ and women $(n=410)$ for seven marathons in the World Marathon Majors Series: Berlin (A), Boston (B), Chicago (C), London (D), New York City (NYC) (E), World Championships (WC) (F), and the Olympics (G). Each marathon is plotted with the mean \pm SEM age for the men and women for each year (circles). The triangles on the right side of each panel represent the mean of all the years (total) for men and women in each marathon. Chicago (C) and London (D) marathons showed a main effect of $\operatorname{sex}(* P<0.05)$, and both showed

Medicine \& Science in Sports \& Exercise, Vol. 43, No. 4 (May 2011): pg. 656-664. DOI. This article is (C) American College of Sports Medicine and permission has been granted for this version to appear in e-Publications@Marquette. American College of Sports Medicine does not grant permission for this article to be further copied/distributed or hosted elsewhere without the express permission from American College of Sports Medicine. 
NOT THE PUBLISHED VERSION; this is the author's final, peer-reviewed manuscript. The published version may be accessed by following the link in the citation at the bottom of the page.

interactions of sex and year. Chicago had different quadratic trends for the men and women (*difference in age between men and women at $P<0.05$.

\section{Figure 3}
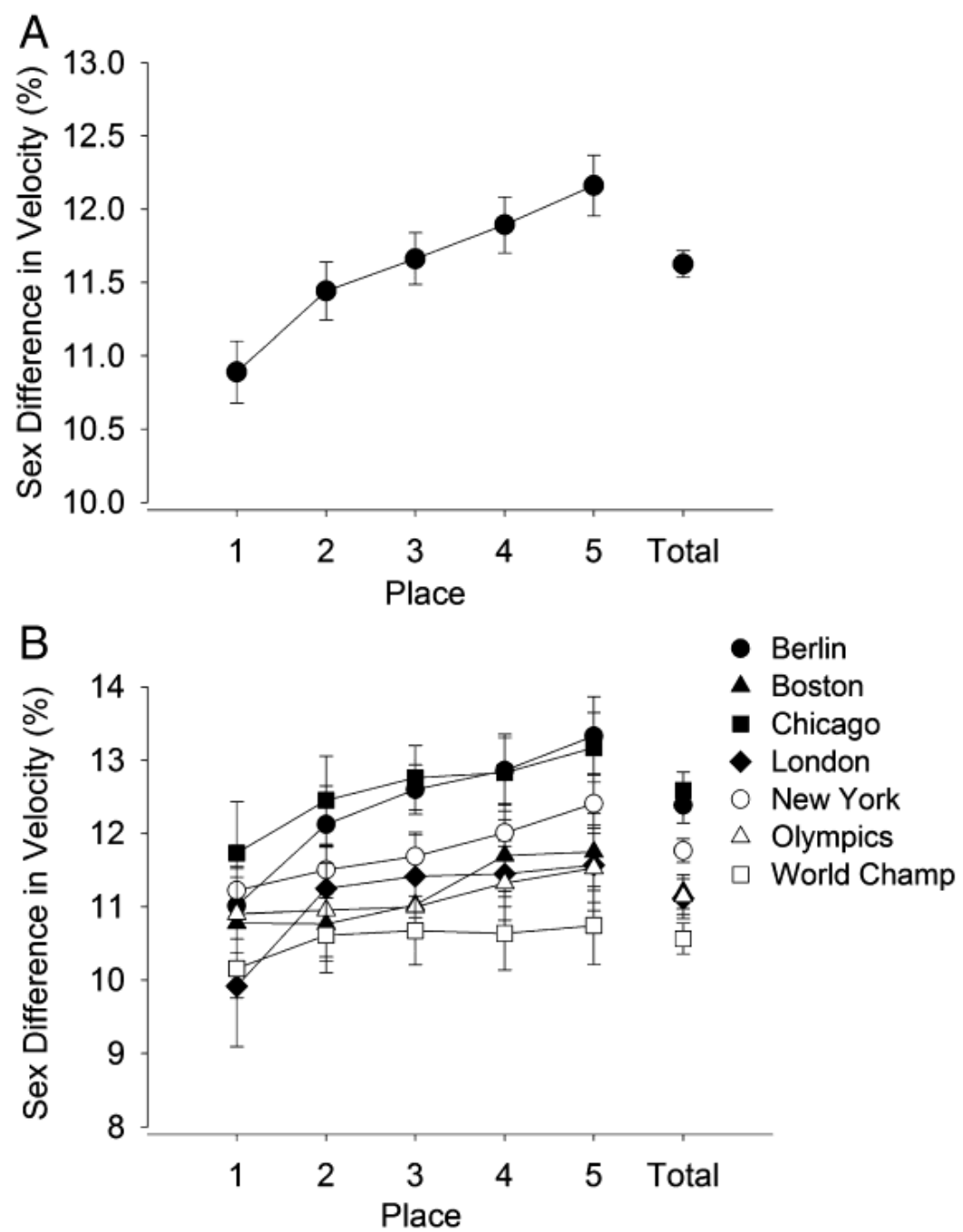

Sex difference in running velocity as a percentage (mean \pm SEM) across the five first places for the seven marathons in the World Marathon Majors Series when they are pooled (A) and for each marathon shown separately (B). The mean sex difference in running velocity of the first to fifth place runners is shown on the right side of each graph (Total). The sex difference increased between first and fifth place for all marathons.

Medicine \& Science in Sports \& Exercise, Vol. 43, No. 4 (May 2011): pg. 656-664. DOI. This article is (C) American College of Sports Medicine and permission has been granted for this version to appear in e-Publications@Marquette. American College of Sports Medicine does not grant permission for this article to be further copied/distributed or hosted elsewhere without the express permission from American College of Sports Medicine. 
NOT THE PUBLISHED VERSION; this is the author's final, peer-reviewed manuscript. The published version may be accessed by following the link in the citation at the bottom of the page.

\section{Figure 4}
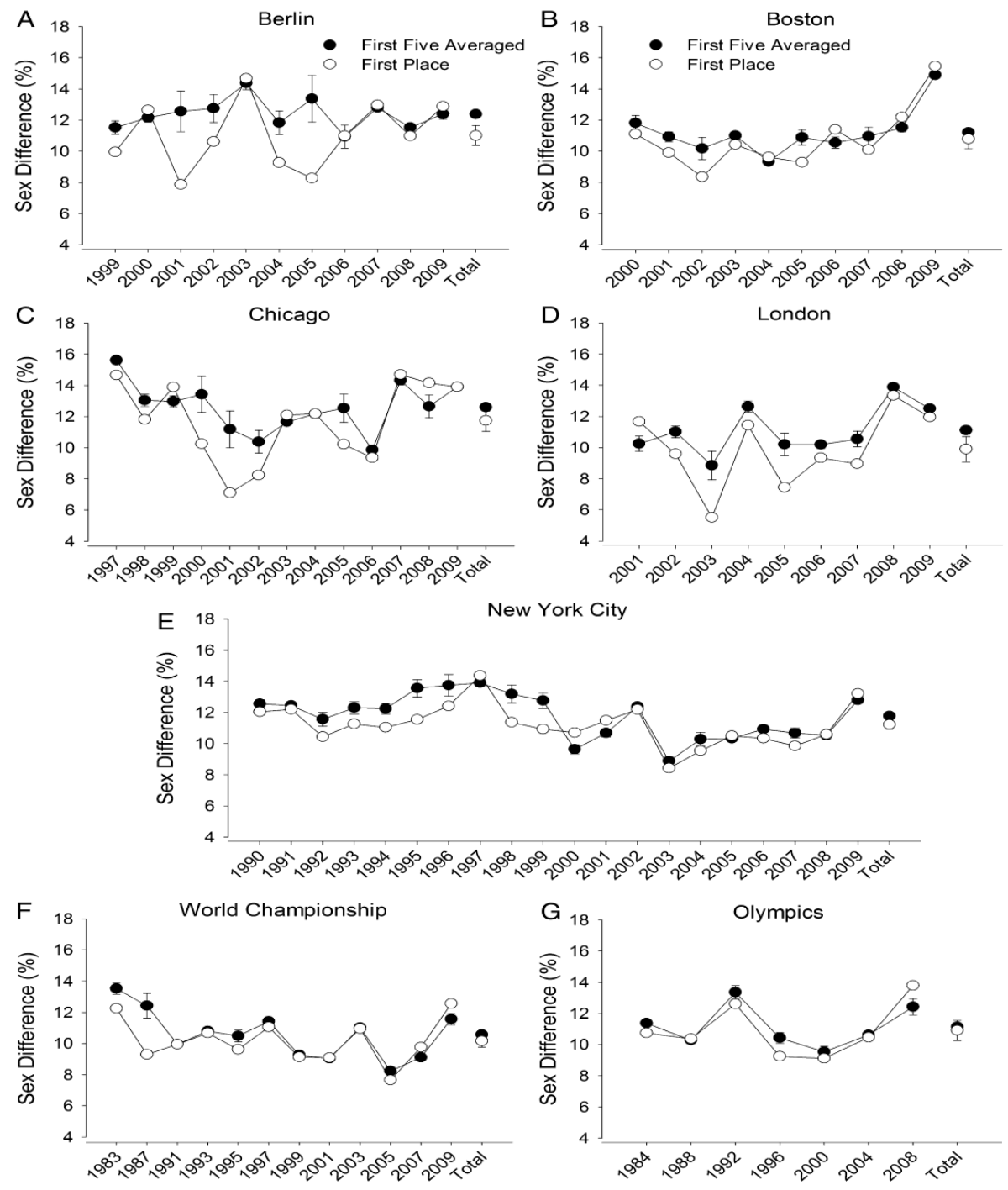

Sex difference in running velocity as a percentage (mean \pm SEM) for seven marathons in the World marathon Majors Series: Berlin (A), Boston (B), Chicago (C), London (D), New York City (E), World Championships (F), and Olympics (G). Each marathon is plotted with the mean \pm SEM sex difference for the first five men and women in filled circles and the sex difference for the first-placed men and women in the open circles for each year examined. The mean sex difference of all the years (total) is shown on the right side of each panel. The graphs represent the data from 410 men and 410 women. 
NOT THE PUBLISHED VERSION; this is the author's final, peer-reviewed manuscript. The published version may be accessed by following the link in the citation at the bottom of the page.

\section{Table 1: Age of men and women runners in the World Marathon Major Series}

\begin{tabular}{|c|c|c|c|c|c|c|c|c|}
\hline \multirow[b]{2}{*}{ Marathon Race } & \multirow[b]{2}{*}{ Years (Range) } & \multirow[b]{2}{*}{ No. of Years } & \multicolumn{2}{|c|}{$n$} & \multicolumn{2}{|c|}{ Age of First Five (yr) } & \multicolumn{2}{|c|}{ Age of First Place (yr) } \\
\hline & & & Men & Women & Men & Women & Men & Women \\
\hline Berlin & 1999-2009 & 11 & 55 & 55 & $28.7 \pm 3.8$ & $29.1 \pm 4.2$ & $30.1 \pm 4.4$ & $28.3 \pm 4.0$ \\
\hline Boston & 2000-2009 & 10 & 50 & 50 & $28.4 \pm 3.6$ & $29.1 \pm 4.1$ & $28.0 \pm 2.4$ & $28.7 \pm 3.8$ \\
\hline Chicago & $1997-2009$ & 13 & 65 & 65 & $28.8 \pm 3.6$ & $31.3 \pm 4.4^{\star}$ & $26.5 \pm 2.5$ & $31.2 \pm 2.8^{*}$ \\
\hline London & 2001-2009 & 9 & 45 & 45 & $29.4 \pm 4.5$ & $31.5 \pm 3.7^{\star}$ & $26.8 \pm 3.2$ & $30.1 \pm 3.3^{*}$ \\
\hline New York & $1990-2009$ & 20 & 100 & 100 & $29.5 \pm 3.7$ & $30.1 \pm 3.9$ & $28.8 \pm 3.0$ & $29.5 \pm 3.9$ \\
\hline Olympics & $1984-2008$ & 7 & 35 & 35 & $28.1 \pm 4.3$ & $28.6 \pm 4.0$ & $27.0 \pm 6.2$ & $28.4 \pm 4.9$ \\
\hline World Champ & 1983-2009 & 12 & 60 & 60 & $29.0 \pm 3.7$ & $28.0 \pm 4.1$ & $29.3 \pm 4.5$ & $28.5 \pm 4.2$ \\
\hline Total & & & 410 & 410 & $28.9 \pm 3.8$ & $29.8 \pm 4.2$ & $28.2 \pm 3.8$ & $29.4 \pm 3.8$ \\
\hline
\end{tabular}

Shown are the years of data included in the analysis (range and number of years), numbers of men and women and mean age of the winners (first place), and top five men and women marathon runners (averaged) for the seven marathons in the World Marathon Majors Series. Women were older than men for the Chicago and London marathons only ( ${ }^{*}$ women older than men at $\mathrm{P}<0.05$ for that marathon). Values for age are presented as mean \pm SD.

\section{Table 2: Sex differences in marathon running velocity}

TABLE 2. Sex differences in marathon running velocity.

\begin{tabular}{lcc}
\hline Marathon Race & $\begin{array}{c}\text { Sex Difference in } \\
\text { Velocity (\%) }\end{array}$ & $\begin{array}{c}\text { Sex Difference in } \\
\text { Velocity (\%) }\end{array}$ \\
\cline { 2 - 2 } Berlin (1999-2009) & First Place & First Five \\
\hline Boston (2000-2009) & $11.0 \pm 2.1$ & \\
Chicago (1997-2009) & $10.8 \pm 2.0$ & \\
London (2001-2009) & $11.7 \pm 2.5$ & $11.2 \pm 1.8$ \\
New York (1990-2009) & $9.9 \pm 2.5$ & $12.6 \pm 2.0$ \\
Olympics (1984-2008) & $11.2 \pm 1.3$ & $11.1 \pm 1.8$ \\
World Champ (1983-2009) & $10.9 \pm 1.7$ & $11.8 \pm 1.6$ \\
Total & $10.2 \pm 1.4$ & $11.1 \pm 1.4$ \\
\hline
\end{tabular}

Shown are the sex differences in marathon running velocity (mean \pm SD) of the first place and the top five men and women marathon runners (averaged) for the seven marathons in the World Marathon Majors Series. Men were faster than women in ever marathon and place (first to fifth). The sex difference was greatest for the Berlin and Chicago marathons compared with the other marathons $(P<0.05)$. The sex difference for the World Championships, which showed the smallest difference of all the marathons for the first five runners, was less than the Berlin, Chicago, and New York City marathons $(P<0.05)$ but similar to the sex difference for the Boston, London, and Olympic marathons.

Medicine \& Science in Sports \& Exercise, Vol. 43, No. 4 (May 2011): pg. 656-664. DOI. This article is (C) American College of Sports Medicine and permission has been granted for this version to appear in e-Publications@Marquette. American College of Sports Medicine does not grant permission for this article to be further copied/distributed or hosted elsewhere without the express permission from American College of Sports Medicine. 